\title{
Foreign ownership and domestic cooperation for innovation during good and harsh economic times
}

\author{
Antonio García-Sánchez \\ Lecturer of Applied Economics \\ Universidad de Sevilla \\ Avda. Ramón y Cajal, 1 \\ 41018 Sevilla, Spain \\ acichez@us.es \\ Ruth Rama $^{1}$ \\ Research Professor \\ IEGD-CSIC \\ Albasanz, 26-28 \\ Madrid 28037, Spain \\ ruth.rama@cchs.csic.es
}

For the published version, please see:

García-Sánchez, A., \& Rama, R. (2020). Foreign ownership and domestic cooperation for innovation during good and harsh economic times. International Journal of Multinational Corporation Strategy, 3(1), 4-25.

https://www.inderscienceonline.com/doi/abs/10.1504/IJMCS.2020.107674

Antonio Garcia-Sánchez obtained his Ph. D. in Economics from the University of Huelva in 2002. He is a lecturer in Economics at the University of Seville (Department of Economics and Economic History). His research interests include industrial economics, economics of innovation and technological change, and cultural economics (technology driven).

Ruth Rama obtained her Ph D in Economics from the Autonomous University of Barcelona in 1980. She is currently Research Professor at the Institute of Economics, Geography and Demography of the CSIC, the National Research Council of Spain. Her main areas of research are technology sourcing of domestic and foreign firms, and networks of innovators.

Acknowledgements. The authors wish to thank the Editor and the referees for their useful comments and suggestions. They gratefully acknowledge financial support from project ECO2013-41317-R. Ruth Rama also acknowledges financial support from project CSO201679045-C2-1-R. Both projects have been funded by the Spanish Ministry of Economics and Competitiveness.

\footnotetext{
${ }^{1}$ Corresponding author.
} 
Abstract. A sample of firms active in the Spanish Information and Communication Technology sector during 2003-2014 is analysed to assess whether foreign subsidiaries are likely to make a technological contribution to domestic innovative capabilities during expansive phases of the business cycle and during recessions. Domestic firms are used as a control group. Innovative foreign subsidiaries are more likely than non-innovative foreign subsidiaries to cooperate for innovation with local partners. However, the most advanced foreign subsidiaries seem reluctant to engage in local cooperation for innovation. Foreign subsidiaries have shown greater capability than domestic firms in increasing their collaboration with local partners during the 2008 crisis.

Key words: internationalization of R\&D, foreign subsidiaries, cooperation for innovation, ICT sector, crisis, Spain

\section{Introduction}

Multinational enterprises (MNEs) perform R\&D abroad for a variety of reasons, such as adapting their products to local tastes and regulations, and benefitting from local expertise and funding (Rama, 2009). Is the current world expansion of foreign direct investment (FDI) in R\&D (Dunning \& Lundan, 2009; OECD, 2008) likely to contribute towards linking host countries to international sources of upgraded technology? This inquiry is most timely since competition between countries to attract R\&D-intensive foreign direct investment (FDI) has markedly increased in recent years (Guimón, 2009). Most academics and policy-makers believe that foreign firms may be a source of up-to-date technology for host countries. The need for transfers of technology is especially acute in those countries that are not at the forefront of science and technology; this is the case in many European peripheral countries and emerging economies. Reviews of the empirical literature suggest that technology transfers are facilitated when foreign subsidiaries (FSubs) build local linkages (see UNCTAD, 2001; Rama, 2009). One such linkage is cooperation for innovation with local partners, also referred to in the literature and in this article as collaboration for innovation. 
However, a wide range of circumstances can potentially limit the local embeddedness of the FSub. Recessions may put the brakes on the decision of the foreign firm to cooperate locally for innovation since local innovators unburdened by financial constraints may be difficult to find. Cooperative behaviour in the host country is also influenced by characteristics of the foreign firm, such as its technological level and its line of business (Dachs et al., 2008; Guimón \& Salazar-Elena, 2015; Holl \& Rama, 2014; Jaklič et al., 2014; Manolopoulos et al., 2005; Santangelo, 2009; Zhang et al., 2018). "Cooperative" refers here to cooperation for innovation.

The possible association between foreign ownership and local cooperation for innovation represents a complex and incompletely understood question. Mostly based on the empirical evidence provided by the Community Innovation Survey (CIS) of the European Union (EU), previous studies have offered major insights into this relationship. However, research results remain inconclusive and certain aspects of the question deserve further analysis. Firstly, although there are exceptions (Ebersberger et al., 2011; Holl and Rama, 2014; Knell and Srholec, 2006; Molero and Heijs, 2002; do Couto e Silva Neto et al., 2013; Srholec, 2009), most analyses on the possible impact of foreign ownership on local cooperation for innovation focus on highly industrialized countries. More inquiries regarding European peripheral countries and emerging economies are necessary to complete the picture since the risk of branch-plant syndrome is greater in countries that are not technology leaders (Ebersberger et al., 2011; Srholec, 2009). The branch-plant syndrome has been characterized by the poor integration of FSubs into the local milieu (Phelps, 1993). Secondly, most previous studies are based on cross-sectional analyses. Quantitative sectoral studies remain rare. However, the heterogeneity of patterns of innovation across sectors has been clearly established (Malerba, 2005) and, within the same host country, the cooperative arrangements of FSubs may differ by sector (Ebersberger et al., 2011; García Sánchez et al., 2016a, 2016b; Guimón \& Salazar-Elena, 2015). Quantitative sectoral studies may lead to a more precise understanding of the role of foreign ownership. Innovation in ICT displays specific characteristics: ICT firms tend to be more innovative than firms active in other sectors; innovation is multipurpose and pervasive in society; innovations emerge and diffuse very rapidly but also become outdated very rapidly 
(Wintjes, 2016). It is important to reduce the problem of unobserved heterogeneity since, as noted by Damijan et al. (2013), "the heterogeneity of firms in terms of absorptive capacity, size, productivity and technology levels affects the results" of analyses of interactions between domestic firms and foreign subsidiaries. Thirdly, the question of the possible contributions of FSubs in terms of updated technology remains elusive in the literature.

Finally, the relationship between foreign ownership and the probability of domestic cooperation for innovation has been tested during "normal" phases of the business cycle (Section 2). To the best of our knowledge, no studies have yet tackled this relationship covering hard economic times. Since open innovation may contribute towards mitigating the difficulties and risks involved in a global financial crisis (D’Agostino \& Moreno, 2017; Zouaghi et al., 2018), it should be ascertained whether FSubs may help the host economy to cope with the often devastating effects of a global crisis on innovation. Williams and Ecken (2011) note that the embeddedness of R\&D subsidiaries should not be considered static and advise researchers to take longitudinal elements into account since certain conditions may change, such as the availability of resources to the domestic partners of the multinational. This article strives to contribute towards a better understanding of these under-researched questions.

For our study, the Spanish Information and Communication Technology (ICT) sector was selected for various reasons, but mainly due to its broad applicability. Information and communication technology is at the origin of many general-purpose technologies, such as photonics, microelectronics and nanoelectronics, semiconductors, and advanced technology manufacturing, which may contribute towards transforming the face of economies and societies. ICT constitutes a key area that underpins major ongoing industrial transformations. The Digital Agenda for Europe represents one of the pillars of the Europe 2020 strategy for growth (Mas et al., 2018). Industry 4.0 may contribute to the competitiveness of national industries by improving connections between various segments of the value-chain, facilitating quality controls, and reducing factory costs. The second reason is that the ICT sector is crucial for Spain since it supports several of its most competitive industries. 
Worldwide, the automobile industry is currently undergoing a major technological shift, which is related to the increased importance of ICT in the total added value of vehicles. One study claims that "traditional automakers need to stop thinking about cars as they were when Henry Ford built the first Model $T$ and begin thinking about them as a smartphone with wheels" (Butler \& Martin, 2016, p.33). The emergence of electric vehicles, autonomous vehicles, connected cars, shared services platforms, and new battery technologies have posed new challenges as well as opportunities. These developments are causing an upheaval in markets and companies (Ferràs-Hernández et al., 2017; Teece, 2018), and greatly affect Spain, the second largest EU producer of cars after Germany ${ }^{1}$ and the primary producer of industrial vehicles ${ }^{2}$. Moreover, $85 \%$ of the Spanish production of cars is exported, as is $60 \%$ of its electronic components for automobiles. The Spanish machine tool industry, another major client of the national ICT sector, is the third-largest producer and exporter of machine tools in the $\mathrm{EU}^{3}$. However, according to patent analysis, Spain has no Revealed Technological Advantages (RTA) in ICT (Molero \& Garcia, 2008) and there is a fear that the country could not adapt to the new developments in these key export industries. Logically, the "value" of a potential international transfer of technology is greater for host industries that enjoy no RTA since such a transfer may facilitate the acquisition of state-of-the-art technology unavailable at national level. Furthermore, Spain has recently become an exporter of capital in electronics and, especially, in telecommunications (FernándezOtheo \& Myro, 2014; Rama \& Ferguson, 2007; Valdaliso et al., 2011).

Firstly, we investigate whether innovative FSubs are more likely to cooperate locally for innovation than non-innovative FSubs. This is a crucial inquiry from the point of view of host countries, since non-innovative FSubs contribute little to the host country in terms of state-of-the-art knowledge and may, instead, crowd out domestic companies (Buckley et al., 2007). Secondly, we ask whether the local cooperative behaviour of FSubs has been affected by the 2008 financial crisis. Spain is a good choice for analysis since it is one of the European countries worst hit by the 2008 financial crisis. During the crisis, Spanish enterprises often abandoned R\&D (Holl \& Rama, 2016; Zouaghi \& Sánchez, 2016). As did many other countries, Spain suffered a credit crunch and cuts in public finance devoted to innovation (Cruz-Castro et al., 2018). Our objective is to determine whether FSubs maintained their local 
collaboration for innovation during the crisis or alternatively, whether they preferred to halt collaboration. In attempting to respond to these inquiries, domestic firms are used as a control group since we aim to identify the specificities of FSubs. Ultimately, we want to ascertain whether FSubs are likely to make a technological contribution towards domestic innovative capabilities in the ICT sector.

The analysis of the Spanish case may be of interest to other peripheral European countries and emerging economies that are striving to upgrade this key sector.

Section 2 deals with the literature review and introduces our research questions. Section 3 presents the contextual setting; Section 4, the data and methodology; and Section 5, the results and discussion. In the last section, the conclusions are drawn.

\section{Review of the literature and research questions}

The review of the literature draws from several strands of theory: the literature on cooperation for innovation; International Business (IB) theory; network theory, and theories of technological change.

\subsection{Sourcing of technology}

Foreign subsidiaries use different strategies for sourcing local technology (Holl \& Rama, 2014; Zhang et al., 2018) but cooperation for innovation seems to have a greater potential than the subcontracting of $R \& D$ services or the purchase of $R \& D$ services via the market for the diffusion of new knowledge. Cooperating with a partner to develop a technology or a product implies frequent interactions between the agents involved in the arrangement, while companies subcontract R\&D services for the performance of mere standardized tasks (Beneito, 2006; Dhont-Peltrault \& Pfister, 2011). According to the Resource-Based View (RBV) of the firm, R\&D cooperation provides a solution to the problems that the company is unable to solve by itself (Miotti \& Sachwald, 2003) and certain empirical studies seem to confirm this point of view regarding the ICT sector: for instance, a study detected that, in the Chinese consumer electronics industries, the use of alliances tends to be reserved to solve the most complex problems (Huang \& Holden, 2016), probably those that the company cannot decipher by itself. The product life cycle of certain ICTs is especially rapid 
(Fuller et al., 2017) but the production of innovation in this field involves very longterm horizons and requires tight cooperation for innovation between companies, universities, and research centres (Aschhoff et al., 2010). Therefore, cooperation for innovation is not only a necessity for the generation of new technology, but it also displays a potential for its transfer.

\subsection{Highly innovative foreign subsidiaries}

As stated in Guimón (2009) a particularly important objective of host countries resides nowadays in attracting $R \& D$-intensive foreign firms. One crucial question asks whether innovative FSubs are more likely to collaborate for innovation with local partners than are non-innovative FSubs. The evidence is mixed in this respect. In a sample of manufacturing FSubs operating in Spain, those that are more prone to cooperate locally for innovation display: i) higher innovative intensity than the average firm in their two-digit host industry; ii) a larger share of new products in turnover; iii) a greater number of R\&D employees; and/or iv) a greater-than-average ability to combine internal and external sources of knowledge (García Sánchez et al., 2017). Holl \& Rama (2014), in another sample of Spanish firms, observe that those FSubs engaged in basic research are especially prone to cooperate for innovation with local partners. In a sample of non-European MNEs operating in Spain, Álvarez \& Cantwell (2011) detect that those defined as "innovators" in their study, that is, exporters that had introduced products new to the market, are likely to engage in local R\&D cooperation. Likewise, in a sample of FSubs operating in Greece, it was similarly found that creative subsidiaries are more prone to collaborate intensely with local partners (Manolopoulos et al., 2005).

In contrast, other authors observe that FSubs may fear spillovers of knowledge, and therefore limit their external flows of knowledge in the host country (see, for instance, Caves, 1996; Veugelers \& Cassiman, 2004; Ebersberger \& Herstad, 2012; García Sánchez et al., 2016b). Concerning, specifically, high-tech industries, a study on the semiconductor industry observes that MNEs have been wary of improving the technical capabilities of their own FSubs in China or of outsourcing R\&D to local firms, their objective being to keep design activities in the headquarters of the company 
(Fuller, 2014). Studies on FSubs with investments in ICT located in Costa Rica (Ciravegna \& Giuliani, 2007) and Vietnam (Binh \& Linh, 2013) show that these companies often limit their involvement in local cooperation for innovation ( $\mathrm{LCl}$ ) to minor technological aspects or to specific types of local partners, such as public research centres. As shown below, FSubs that have interests in high-tech industries may also follow a restrictive technological strategy in industrialized countries. In a set of Spanish manufacturing industries, including electronics industries, characterized by rapid worldwide technological change, FSubs are more prone than domestic business groups (DomGs) to engage in $\mathrm{LCl}$; however, the association between foreign ownership and $\mathrm{LCl}$ is weakened in a subsample of highly innovative firms (García Sánchez et al., 2016a). In a study on European and Asian subsidiaries active in the US semiconductor industry, Perri and Andersson (2014) observe that "the most advanced subsidiaries, which own highly valuable knowledge and superior technology, are the ones contributing less to the local knowledge network" (p.73).

As shown below, a possible reason is the limited local embeddedness of the MNE. Economic Sociology proposes that social networks affect the flow and quality of information in that they provide an important tool for preventing and punishing "freerider" economic behaviour and generate trust between participants (for a review, see Granovetter, 2005). According to the aforementioned author, economic activities are embedded in social structures and networks. Since the "social capital" of the FSubs in their host country is often limited, the firm may face high transaction costs (Williamson, 1985). The literature on IB maintains that FSubs often incur a liability of foreignness due to the social and cultural barriers that these companies encounter in host countries (Zaheer, 1995). This circumstance, in turn, is likely to reduce their possibilities of cooperating with innovative domestic projects since trust between partners is an essential ingredient of open innovation (Love \& Roper, 2004). The discussion suggests that innovative FSubs are not necessarily more likely than noninnovative FSubs to engage in $\mathrm{LCl}$.

Therefore, we ask: 
RQ1: Are innovative FSubs more prone than non-innovative FSubs to cooperate for innovation with local partners?

As stated, we use domestic firms as a control group.

\subsection{Local cooperation for innovation during harsh economic times}

Most analyses of crises support the thesis that innovation tends to be pro-cyclical, i.e. that investment in innovation decreases during downturns and increases during upturns (see, for instance, Brzozowski \& Cucculelli, 2016; Cincera et al., 2012; Geroski \& Walters, 1995). However, firms are not homogenous in this respect: during the 2008 crisis, firms active in high-tech sectors have been prone to displaying countercyclical innovative strategies, compared to firms active in low-tech sectors (Brzozowski \& Cucculelli, 2016; Zouaghi et al., 2018). Moreover, certain firms, whatever their sector, maintained or even increased their R\&D investment during the crisis (Archibugi et al., 2013; Cincera et al., 2012; Hansen \& Nybakk, 2018; Holl \& Rama, 2016; Paunov, 2012; Zouaghi et al., 2018). In the aforementioned studies, superior innovative performance during a downturn is explained by the adoption of open innovation practices and other factors, such as the large size of the company.

D'Agostino \& Moreno (2017) opine that the effects of the 2008 financial crisis on the cooperative activities of all types of firms have been insufficiently considered in the literature. In theory, a crisis may either encourage or discourage cooperation for innovation. On the one hand, cuts in public expenditure may induce firms to become close innovators since, in certain countries, government support for innovation contributes towards shaping the collaborations of firms; this may be especially the case in European peripheral countries or in emerging economies, as shown by a study on Brazil (Jugend et al., 2018). On the other hand, following the RBV of the firm, cooperation for innovation is a solution to problems the company cannot solve by itself (Miotti \& Sachwald, 2003), for instance, firms enduring credit shortages may join efforts to fund innovation. As shown below, the few studies available do not suggest, however, that firms are more prone to cooperation during a crisis. An analysis of Japanese electronics firms concludes that R\&D alliances displayed little, if any, counter-cyclical tendency over several crises of the 1980s and the 1990s (Lincoln 
et al., 2017). On analysing Spanish companies clustered in an industrial district, Hoffmann et al. (2017) observed that, during the 2008 crisis, firms decreased their collaborations, except for vertical cooperation. A Pan European study finds that the 2008 crisis had a deteriorating effect on university-industry cooperation as measured by co-authored research publications, even when funding and other variables that may influence cooperation are checked (Azagra-Caro et al, 2019).

Concerning, specifically, multinationals, the emerging field of MNE resilience has largely focused on the effect of downturns on the financial performance of these companies, and not on their innovative performance (Fainshmidt et al., 2017; Manolopoulos, 2018). However, a few studies in the field of innovative resilience take into account the specific technological strategy of MNEs during the 2008 crisis. In a sample of European firms that operate in innovation-intensive sectors, Archibugi et al. (2013) find that companies with investments abroad, a proxy for MNEs in their study, were less likely than uninational companies to increase their R\&D investments during the 2008 crisis. On analysing Spanish data, Holl and Rama (2016) observe that foreign ownership had a neutral effect on the probability that a company adopted a countercyclical strategy during the 2008 crisis, even when size, technological leadership, and other features of firms were considered. By evaluating the probability that a firm generates radical innovations during a crisis, another study into the case of Spain also suggests that foreign ownership has a neutral effect (D'Agostino \& Moreno, 2017). From the discussion, one can conjecture that MNEs were unlikely to adopt a countercyclical technological strategy during the 2008 global crisis.

To the best of our knowledge, no previous study has yet focused on the specific cooperative behaviour of FSubs during an economic downturn. Most of the literature on the aforementioned relationship is based on pre-crisis evidence (see, for instance, Veugelers \& Cassiman, 2004; Arvanitis \& Bolli, 2013; Dach et al., 2008; Srholec, 2009; Ebersberger et al., 2011; Ebersberger \& Herstad, 2012; García Sánchez et al., 2016a). Nevertheless, there are exceptions: for instance, Holl \& Rama (2014) analyse data for 2005-2009; Guimón \& Salazar-Elena (2015), for 2005-2011; and Cozza \& Zanfei (2016) and Cozza et al. (2018), for 2001-2010. The aforementioned studies cover only the first few years of the 2008 crisis, which was prolonged in certain countries, such as 
Spain. Logically, they do not strive to identify changes in the cooperative behaviour of FSubs from the pre-crisis period to the in-crisis period, as we do herein by analysing panel data for the complete in-crisis period in Spain (2008-2014). Concerning the cooperative behaviour of FSubs during the crisis, very little guidance is available in the literature on foreign ownership and $\mathrm{LCl}$.

However, evolutionary theories of IB, which maintain that multinationals evolve with their environment, may provide some guidance (Cantwell et al., 2010). Their argument states that, as a response to uncertainty in the host country, MNEs may shift towards networked forms of organization that provide more flexibility. In our view, this theory would predict a greater involvement of the MNE in a networked form of innovation, such as $\mathrm{LCl}$, during a crisis, since this form of organization would help the multinational share the costs and risks of innovation with local partners. Nevertheless, in the scarce evidence available, no suggestion is made regarding this organizational shift during the 2008 crisis. Two studies on Italy and on eight Latin American countries suggest that, during the crisis, FSubs and leaders of GVCs have maintained or even augmented their innovative activities, while their local suppliers have been likely to reduce or terminate theirs (Brancati et al., 2017; Paunov, 2012). A speculative interpretation of the aforementioned findings is that FSubs may have reduced their involvement in local R\&D cooperation during the crisis, while still continuing with their own in-house projects. Consequently, we formulate the following question:

RQ2: Did FSubs reduce their local collaboration for innovation during the 2008 crisis?

\section{Context Setting}

In 2015, the Spanish ICT sector ranked fifth in the EU in terms of added value, after those of Germany, the UK, France, and Italy (Mas et al., 2018). The number of Spanish ICT firms increased from 29,838 in 2011 to 33,176 in 2016, whereby the most dynamic subsectors in this regard were informatics and the media. According to official data, total ICT turnover increased from 89,203 M€ in 2013 to 105,868 M€ in 
2016. In 2017, employment amounted to approximately half a million people, and added value was 4.2\% of the Spanish GDP (Muñoz López et al., 2017).

The subcontracting of production plays a major role in this Spanish sector (Holl \& Rama, 2009; López-Bayon \& Gonzalez-Diaz, 2010) and many firms operate exclusively in "business-to-business" markets. As stated earlier, the ICT sector is a major supplier to two important national export industries: automobiles and machine tools. ICT subcontractors display significant links with the national aeronautic industry (Díaz-Mora, 2008). Large domestic groups specialising in defence electronics and cyber-defence (Calvo, 2019) have been involved in European projects, such as those of Airbus and European Fighter.

In 2015, Spanish outward stock of FDI in ICT amounted to 47,261 M€ (Muñoz López et al., 2017). Telefonica, a very large native multinational, played a key role in the internationalization of telecommunication services, while the protagonists of the internationalisation of the computing and electronics industries are companies of all sizes (Esteve \& Rodríguez, 2014; Rama \& Ferguson, 2007; Valdaliso et al., 2011). Foreign direct Investment is also substantial; in 2015, the inward stock position of FDI in Spanish ICT industries was 31,583 M€ (Muñoz López et al., 2017).

\section{Methodology}

Real LCl data is used, obtained from the PITEC database, which provides anonymised micro-data on both domestic and foreign companies. PITEC is the Spanish Technological Innovation Panel collected by the Spanish National Statistics Institute as a contribution to the CIS of the EU. Compared to other CIS-type surveys, PITEC has the advantage of providing data collected every year (while CIS has a two-year periodicity). It should be noted that non-innovators are excluded from our sample, since PITEC poses questions about cooperation for innovation only to firms broadly defined by the questionnaire as "innovative": companies that have launched new products onto the market, introduced new industrial processes, abandoned innovative projects within the two years prior to the survey, or have ongoing innovative activities. Other CIS-type surveys display the same features (Srholec, 2009; Veugelers \& Cassiman, 2004). Our sample is statistically representative of ICT firms located in Spain in 2003 - 2014. PITEC 
distinguishes between two different categories of firms: unaffiliated companies and firms belonging to a group. Within the latter, information is provided regarding the location of the headquarters of the company. If they are located in a foreign country, then the company is classified here as an FSub, and if not, then the company is classified as a DomG, while companies not belonging to a group are classified as unaffiliated domestic firms (UDF). We take into account the nature of domestic firms (affiliated or unaffiliated) since group membership seems to influence the propensity to cooperate (Annique Un \& Romero-Martínez, 2009; Ebersberger et al., 2011; Holl \& Rama, 2014; Molero \& Heijs, 2002).

We perform an econometric analysis in order to study factors significantly influencing the probability that a firm cooperates locally for innovation. Our research strategy consists of an iterative estimation of logit models with panel data. In order to capture technological differences between cooperative and non-cooperative companies within each class of firms (UDF, DomG, and FSub), our sample is segmented into three subsamples, for each of which a logit model is estimated:

$$
P\left(\text { LocCoopinn }=1 \mid X_{i}^{T}, \beta^{T}, \alpha_{i}\right)=\Lambda\left(\alpha_{i}+\beta^{T} X_{i}^{T}\right)
$$

Variables

Appendix 1 displays the definitions of the variables. The correlation matrix shows no evidence of multicollinearity problems (Appendix 2).

\section{Dependent variable}

LocCoopInn (Local cooperation for innovation). As in the majority of studies on cooperation for innovation (Holl \& Rama, 2014; Srholec, 2014; Veugelers \& Cassiman, 2004), our dependent variable is a dummy that indicates whether the focal company cooperated for innovation with external partners located in the host country. "External" refers here to partners located in Spain that are not part of the company and/or the business group, such as local universities. Cooperative activities are defined here as two separate organisations joining forces to share and develop 
knowledge in order to enhance their technological performance. Cooperation for innovation includes R\&D cooperation but not the acquisition of R\&D services via the market or via R\&D subcontracting.

\section{Independent variables}

The following independent variables denote intensity as a comparison with the twodigit host industry (domestic and foreign firms included); for instance, above-average R\&D internal expenditures. Two-digit industries include: informatics, electronics and optical products, telecommunications; computer programming, consultancy and related activities; other information and communication services; artistic broadcasting and entertainment activities.

This methodology strives to ascertain the traits and capabilities of the host industry. Our objective is to understand the degree of embeddedness of the FSub when characteristics of the host industry are taken into account. Intensity is indicated by an "i_" before the name of the variable. Innovation-related variables are employed to assess whether quality ICT foreign investment is likely to be involved in LCI (RQ1). Following previous studies and the criteria of the Oslo Manual, a comprehensive approach to innovation is adopted (Ebersberger et al., 2011; García Sánchez et al., 2016a; Holl \& Rama, 2014). The use of several innovation variables may provide a nuanced picture of the possible contributions of FSubs to the NIS. The following variables are dummies that indicate whether the focal firm is more innovationintensive than the average firm that operates in its two-digit industry. When the variables display a positive, statistically significant coefficient, then the focal firm is more innovation-intensive than average. In this set of innovation variables, our variables of interest are:

i_intRDexp: Internal R\&D expenditures. This variable reflects a high commitment to R\&D on the part of the firm and is the sole innovation variable taken into account in certain studies to characterize the technological strength of a firm.

i_newmar: Share of products new to the market in turnover. Certain studies consider this variable essential for the definition of innovators or, specifically, of 
radical innovators (Zouaghi et al., 2018; Álvarez \& Cantwell, 2011) since it points to the ability of the firm to introduce primary innovation into the market.

As a complement, we analyse other variables that also denote innovative intensity:

i_extRDexp: External R\&D expenditures.

i_other InnExp: Innovation expenditures other than R\&D, such as acquisitions of licences related to use of patents.

i_RDpers: Number of employees involved in internal R\&D. Following Cohen and Levinthal (1989), this variable indicates whether the focal firm enjoys, at least potentially, more absorptive capacity than does the average company: a crucial consideration for a firm striving to benefit from cooperation for innovation.

i_newent: Share of products new to the enterprise in turnover. Following Zouaghi et al. (2018), this variable is employed to assess the capacity of the firm to produce incremental innovation.

i_interinfo: This variable denotes the perception of the firm regarding the usefulness of internal information coming from both the company itself and its group. Combining internal and external information inputs can improve the productivity of inhouse R\&D (Di Guardo \& Harrigan, 2012). MNEs are likely to value their own sources more highly than domestic firms value their own sources (Dachs et al., 2008; Molero \& Heijs, 2002). Certain studies suggest that external knowledge seems only to supplement their internal sources (García Sánchez et al., 2017; Manolopoulos et al., 2005).

i_ownfund: Share of its own resources in the total resources used by the focal company to finance R\&D. Cross-sectional studies remain inconclusive as to whether credit-rationed firms or firms facing high costs of innovation are more likely to become involved in cooperative arrangements (Carboni, 2013; López, 2008; Miotti \& Satchwald, 2003). In a study on the Spanish food and beverage industry, FSubs that display a larger-than-average share of their own funding for innovation are more likely 
to cooperate locally for innovation than FSubs that display a smaller-than-average share (García Sánchez et al., 2016b).

Obstacles. Herein, 11 obstacles to innovation are taken into account. Obstacles were aggregated through factor analysis and re-codified into four categories. Our independent variables for obstacles include: i_knowobst, i_econobst, i_marketobst, and i_competobst. In this set, $\boldsymbol{i}_{\mathbf{k}}$ knowobst is our variable of interest since it may indicate, according to PITEC, key characteristics of advanced firms, such as fewer difficulties than average in accessing knowledge, and in finding qualified employees or technological/market information.

As stated earlier, an "i_" before the name of the variable indicates that we are comparing the focal firm with the average company in its two-digit industry.

crisis. This is our variable of interest concerning RQ2. The 2008-2014 period is used here to signal the in-crisis cooperative performance of firms. The final year of the crisis is taken as 2014 since this is the first year when an increase in the Spanish GDP is displayed after its inception (Zouaghi et al., 2018).

Following previous studies (Ebersberger et al., 2011; Holl \& Rama, 2014; Miotti \& Satchwald, 2003; Belderbos et al., 2015), we control for the size, export activities, and previous cooperative experience of the company.

i_size: Size of the firm measured as the number of employees.

I_size: Logarithm of the number of employees.

mdoue: Indicates whether the focal firm exports goods or services to the EU market.

previousLocCoop. Belderbos et al. (2015) find that persistence is the most common pattern of collaboration in a sample of Spanish manufacturing and service firms. Firms that cooperated previously may have acquired some experience concerning the identification of suitable partners and of joint innovative projects. They are therefore probably more likely to engage in $\mathrm{LCl}$ than those that lack recent cooperation experience. Furthermore, previous experience in the host country may have reduced 
the liability of foreignness faced by FSubs. On the other hand, an increase in cooperative activities may be attributable to this cumulative effect and not to the crisis, and hence the need to control for previous cooperative experience. Following Belderbos et al. (2015), the variable takes the value 1 when the focal firm was engaged in $\mathrm{LCl}$ in the two previous consecutive years, 0 otherwise. As observed by the aforementioned authors, there is little scope for longer survey lags, given the limited panel structure of the PITEC data.

\section{Results and Discussion}

\subsection{Descriptive statistics}

Our sample includes nearly 14,000 observations for 2003-2014. UDFs account for $53 \%$ of the sample firms, DomGs for $35 \%$, and FSubs for $12 \%$. Most of the sample companies operate in the subsector of programming and consulting (53\%) and informatics products (22\%); the rest are in other informatics services, telecommunications, etc. FSubs are overrepresented in telecommunications and other informatics services. DomGs spend more money on innovation than do the two other types of firm, while FSubs stand out for their large size rather than for their R\&D intensity (Table 1).

\section{Table 1}

\subsection{Models}

The estimation is repeated for three subsamples of, respectively, UDFs, DomGs, and FSubs (Table 2, columns 1, 3, and 5). The objective here is to detect whether cooperative companies are more innovation intensive than are non-cooperative companies.

\section{Table 2}

Column 5 shows the distinctive characteristics of, specifically, FSubs engaged in LCl. Compared to non-cooperative FSubs, cooperative FSubs display higher-thanaverage $R \& D$ employment and a greater share of improved products in turnover (i_RDpers and i_newent are both positively associated with LocCoopInn, $p \leq 0.001$ and 
$p \leq 0.01$, respectively). Higher-than-average $R \& D$ employment increases the probability that an FSub engages in $\mathrm{LCl}$ by $17 \%$, while a large share of incremental innovation in turnover increases this probability by $11 \%$ (column 6 ). Compared to non-cooperative FSubs, cooperative FSubs value their internal sources of information highly (i_interinfo displays a significant positive association with LocCooplnn, $p \leq 0.01$ ). At first sight, these results suggest that innovative FSubs are more prone than non-innovative FSubs to cooperate for innovation with local partners (RQ1).

Turning now to our variables of interest in column 5, we note that $\mathbf{i}$ newmar and i_intRDexp display both significant negative associations with LocCoopInn ( $p \leq 0.10$ and $p \leq 0.01$, respectively), and that $\mathbf{i}$ knowobst has a significant positive association $(p \leq 0.10)$. These results suggest that the non-cooperative FSubs of the sample are more likely than average to: i) display a higher share of radically new products in turnover; ii) invest in internal R\&D; and iii) face fewer knowledge obstacles to innovation. A higher-than-average share of radical innovation in turnover reduces the probability that an FSub engages in $\mathrm{LCl}$ by more than $8 \%$, while a higher-thanaverage expenditure in internal $R \& D$ reduces this probability by $11 \%$ (column 6 ). Experiencing fewer knowledge obstacles than average reduces this probability by $6 \%$. These results introduce an interesting nuance to our response (RQ2). As stated in the paragraph above, innovation-intensive FSubs are inclined, generally speaking, to cooperate with local partners. However, the most advanced FSubs, that is, those with significant commitment to $R \& D$, great ability to be first to introduce innovations into the market, and/or an outstanding level of knowledge, are the least prone to engage in $\mathrm{LCl}$.

In contrast, the UDFs spending more than average on internal R\&D are likely to cooperate with local partners (Table 2, column 1). Moreover, among both UDFs and DomGs, radical innovators are likely to cooperate with local partners. In columns 1 and 3, i_newmar displays significant positive associations with LocCoopInn for UDFs $(p \leq 0.05)$ and for DomGs $(p \leq 0.001)$. A possible explanation for differences in the behaviour of advanced firms is that FSubs may face high transaction costs due to their limited social capital in the host country, hence their fear of involuntary spillovers of knowledge when innovation is especially valuable. This is the case of new-to-the- 
market innovation. This interpretation is in accordance with theories of IB that maintain that MNEs probably internalize their most important innovative activities (Caves, 1996). In contrast, the greater embeddedness of domestic firms in the milieu promotes trust between potential partners and, in turn, may induce these firms to cooperate locally even when radical innovation is involved. Analyses of domestic ICT firms in Spain and elsewhere seem to corroborate this interpretation (Paija, 2001; Rama \& Ferguson, 2007; Suárez-Villa \& Han, 1990; Valdaliso et al., 2011).

The crisis variable displays a significant positive association with LocCoopInn for FSubs $(p \leq 0.05)$ but not for domestic firms. While the economic downturn probably encourages the cooperative activities of FSubs, it seems to have had no effect on those of domestic firms. This responds to RQ2. One possible explanation is that FSubs may have endured fewer financial difficulties than have domestic firms, owing to their easier access to international funding. Furthermore, the different types of partnerships in which firms are engaged may also play a role. Unreported results of a Pearson $X^{2}$ test and of Cramer's $V$ test (available upon request) suggest that the sample FSubs are clearly more likely than the sample domestic firms to engage in partnerships with local clients and suppliers. During a crisis, partnerships across the value-chain seem to be preferred by firms, given the need to reduce costs and face the shortage of liquidity (Hoffmann et al., 2017). This may be the case of the sample FSubs. However, this question deserves more attention than can be provided here.

Finally, previousLocCoop has a significant positive association with LocCoopInn for UDFs, DomG, and FSub ( $p \leq 0.001$ in all cases), which suggests that previous cooperative experience facilitates cooperation in all types of firms. This result confirms those of Belderbos et al. (2015). In domestic firms, a large size predicts engagement in $\mathrm{LCl}$ (i_size displays a positive, statistically significant coefficient), but not in FSubs.

\section{Conclusions}

By analysing the Spanish ICT sector, we have striven to ascertain whether foreign subsidiaries are likely to make a technological contribution towards domestic innovative capabilities. Responses are not monochrome. At first sight, innovative 
foreign subsidiaries seem more prone than non-innovative foreign subsidiaries to cooperate for innovation with local partners. Nevertheless, the most advanced foreign subsidiaries are reluctant to engage in such collaboration, probably due to their fear of spillovers of knowledge. Our results confirm those of Perri \& Andersson (2014) for the US in that the most advanced FSubs are those that contribute less to local capabilities in ICT. In our sample, domestic firms seem more likely to transmit sophisticated knowledge. Among these firms, radical innovators and companies with substantial investments in internal R\&D are prone to collaborate with local partners.

However, foreign firms have shown a greater capability than have domestic firms regarding increasing their collaboration with local partners during harsh economic times. Our results confirm evolutionary theories of IB in that MNEs may shift to networked forms of organisation as a response to uncertainty in host countries (Cantwell et al., 2010).

While simultaneously implementing measures to fully profit from the internationalization of R\&D, host countries should bear in mind not to neglect the role of domestic firms, since these companies may be able to locally transmit more advanced knowledge than can foreign subsidiaries, thanks to their greater embeddedness in the milieu.

However, our results show that foreign subsidiaries active in the Spanish ICT sector do not qualify as being technological enclaves. Some transfer of technology is likely to be taking place, even if it is not the most advanced technology; this contribution increased during harsh economic times. This result is intriguing since ICT foreign subsidiaries active in many other host countries tend to remain isolated (Section 2). Our results reveal certain managerial implications that may be useful in the new business panorama. Worldwide, investment restrictions, as measured by the Economic Freedom Index, are increasing and interests supporting globalization are currently weakening in many countries (Witt, 2019). In this new scenario, host governments are likely to become more discerning than in the past regarding the types of foreign direct investment (FDI) to be welcomed and supported. Positive discrimination may increase, as suggested by recent documents of the OECD 
(Organization of Economic Cooperation and Development) on "FDI qualities" 5 . These documents provide host governments with a "tool kit" to attract the types of FDI more likely to contribute towards development, whereby innovation is a priority.

The new panorama opens opportunities for cooperation between local partners and MNEs well endowed with updated technology. However, the objectives of policy-makers may collide with those of the multinationals, which may fear spillovers of knowledge and restrict their external flows of knowledge in the host country (Section 2). The Spanish case suggests that this blocking situation may be surmounted. Subcontracting production to domestic suppliers and other local linkages constitutes a major step towards reducing the transaction costs faced by foreign firms active in ICT in their host countries. In Spain, FSubs that outsource local R\&D propend to cooperate with local partners for innovation (Holl \& Rama, 2014). Subcontracting production is a significant aspect of the strategy of ICT FSubs in Spain (Holl \& Rama, 2009). These local linkages have probably contributed towards facilitating the embeddedness of foreign firms and, in turn, their participation in local networks of innovators. Both outsourcing of production and outsourcing of R\&D may, indirectly, provide a foreign subsidiary with opportunities to cooperate with local innovators for the sake of mutual benefit. This, in turn, may facilitate compliance with the requirements of host governments.

One limitation of our analysis is that, although cooperation of ICT firms with upstream industries is likely to be relevant, the data available remains unsuitable for the detection of inter-industry collaboration. One avenue for future research would involve a detailed analysis of the cooperative strategies of foreign subsidiaries in times of crisis, in terms of the types of local partners and the dimensions of innovative networks.

\section{References}

Álvarez, I., \& Cantwell, J. (2011). International integration and mandates of innovative subsidiaries in Spain. Institutions and Economies, 3(3), 415-444.

Annique Un, C., \& Romero-Martínez, A. M. (2009). Determinants of R\&D collaboration of service firms. Service Business, 3, 373-394. 
Archibugi, D., Filippetti, A., \& Frenz, M. (2013). The impact of the economic crisis on innovation: Evidence from Europe. Technological Forecasting and Social Change, 80(7), 1247-1260.

Arvanitis, S., \& Bolli, T. (2013). A Comparison of National and International Innovation Cooperation in Five European Countries. Review of Industrial Organization, 43(3), 163191.

Argyres, N. (1996). Evidence on the role of firm capabilities in vertical integration decisions. Strategic Management Journal, 17, 129-150.

Aschhoff, B., Crass, D., Cremers, K., Grimpe, C., Rammer, C., Brandes, F., et al. (2010). European competitiveness in key enabling technologies. ZEW Manheim, Germany.

Azagra-Caro, J.M., Tijssen,R.J.W., Tur, E.M., Yegros-Yegros, A. (2019), University-industry scientific production and the Great Recession, Technological Forecasting \& Social Change,139, 210-220.

Belderbos, R., Carree, M., Lokshin, B., \& Fernández Sastre, J. (2015). Inter-temporal patterns of R\&D collaboration and innovative performance. J.Technol Transf, 40(1), 123-137.

Beneito, P. (2006). The innovative performance of in-house and contracted R\&D in terms of patents and utility models. Research Policy, 35, 502-517.

Binh, T. T. C., \& Linh, N. M. (2013). Supplier system and knowledge transfer within the production networks of electronics MNCs in Vietnam. Asian Journal of Technology Innovation, 21(sup1), 119-138.

Brancati, E., Brancati, R., \& Maresca, A. (2017). Global value chains, innovation and performance: firm-level evidence from the Great Recession. Journal of Economic Geography, 17(5), 1039-1073.

Brzozowski, J., \& Cucculelli, M. (2016). Proactive and reactive attitude to crisis: evidence from European firms. Entrepreneurial Business and Economics Review, 4(1), 181-191.

Buckley, P. J., Clegg, J., \& Wang, C.-F. (2007). Is the relationship between inward FDI and spillover effects linear? An empirical examination of the case of China. J Int Bus Stud, 38(3), 447-459.

Butler, F. C., \& Martin, J. A. (2016). The auto industry: adapt to disruptive innovations or risk extinction. Strategic Direction, 32(11), 31-34.

Calvo, A. (2019). Consolidation and rationalization of the public companies in Spain: the information and communication technologies (ICT) holding. Journal of Evolutionary Studies in Business, 4(1), 142-179.

Cantwell, J., Dunning, J. H., \& Lundan, S. M. (2010). An evolutionary approach to understanding international business activity: The co-evolution of MNEs and the institutional environment. Journal of International Business Studies, 41(4), 567-586.

Carboni, O. A. (2013). Heterogeneity in R\&D cooperation: an empirical investigation Structural Change and Economic Dynamics, 25, 48-59.

Caves, R. E. (1996). Multinational enterprise and economic analysis (2nd ed.): Cambridge University Press.

Cincera, M., Cozza, C., Tübke, A., \& Voigt, P. (2012). Doing R\&D or Not (in a Crisis), That Is the Question .... European Planning Studies, 20(9), 1525-1547.

Ciravegna, L., \& Giuliani, E. (2007). MNC-dominated clusters and the upgrading of domestic suppliers: the case of Costa Rican electronics and medical device industries. In R. Leoncini \& S. Montresor (Eds.), Dynamic Capabilities between Firm Organization and Local Systems of Production (pp. 236-263). London and N.Y.: Routledge.

Cozza, C., Perani, G., \& Zanfei, A. (2018). Multinationals and R\&D cooperation: empirical evidence from the Italian R\&D survey. Economia Politica, 35(2), 601-621.

Cozza, C., \& Zanfei, A. (2016). Firm heterogeneity, absorptive capacity and technical linkages with external parties in Italy. The Journal of Technology Transfer, 41(4), 872-890. 
Cruz-Castro, L., Holl, A., Rama, R., \& Sanz-Menéndez, L. (2018). Economic crisis and company R\&D in Spain: do regional and policy factors matter? Industry and Innovation, 25(8), 729-751.

D'Agostino, L. M., \& Moreno, R. (2017). Exploration during turbulent times: an analysis of the relation between cooperation in innovation activities and radical innovation performance during the economic crisis. Industrial and Corporate Change, 27(2), 387-412.

Dachs, B., Ebersberger, B., \& Lööf, H. (2008). The innovative performance of foreign-owned enterprises in small open economies. Journal of Technology Transfer, 33, 393-406.

Damijan, J. P.; Rojec, M.; Majcen, B.; Knell, M. (2013), Impact of Firm Heterogeneity on Direct and Spillover Effects of FDI: Micro Evidence from Ten Transition Countries, Journal of Comparative Economics, 41(3), 895-922.

Dhont-Peltrault, E., \& Pfister, E. (2011). R\&D cooperation versus R\&D subcontracting: empirical evidence from French survey data. Econ. Innov. New Techn., 20(4), 309-341.

Di Guardo, M. C., \& Harrigan, K. R. (2012). Mapping research on strategic alliances and innovation: a co-citation analysis. The Journal of Technology Transfer, 37(6), 789-811.

Díaz-Mora, C. (2008). What factors determine the outsourcing intensity? A dynamic panel data approach for manufacturing industries. Applied Economics, 40, 2509-2521.

do Couto e Silva Neto, F. C., dos Santos, U. P., Parreiras Oliveira, V., de Castro, P. G., de Melo Franco, L. T., \& de Negri, F. (2013). Patterns of interaction between national and multinational corporations and Brazilian universities/public research institutes. Science and Public Policy, 40(3), 281-292.

Dunning, J. H., \& Lundan, S. M. (2009). The internationalization of corporate R\&D: A review of the evidence and some policy implications for home countries. Review of Policy Research, 26(1-2), 13-34.

Ebersberger, B., Herstad, S. J., Iversen, E., Kirner, E., \& Som, O. (2011). Analysis of innovation drivers and barriers in support of better policies. Economic and market intelligence on innovation. Open innovation in Europe: effects, determinants and policy. Oslo: European Commission. Enterprise and Industry.

Ebersberger, B., \& Herstad, S. J. (2012). Go abroad or have strangers visit? On organizational search spaces and local linkages. Journal of Economic Geography, 12, 273-295.

Fainshmidt, S., Nair, A., \& Mallon, M. R. (2017). MNE performance during a crisis: An evolutionary perspective on the role of dynamic managerial capabilities and industry context. International Business Review, 26(6), 1088-1099.

Fernández-Otheo, C. M., \& Myro, R. (2014). La inversión de las empresas españolas en el exterior: patrón sectorial y espacial, y rentabilidad. In R. Myro \& M. E. Álvarez López (Eds.), España en la inversión directa internacional (pp. 245-296). Madrid: Instituto de Esudios Económicos.

Ferràs-Hernández, X., Tarrats-Pons, E., \& Arimany-Serrat, N. (2017). Disruption in the automotive industry: A Cambrian moment. Business Horizons, 60(6), 855-863.

Fuller, D. B. (2014). Chip design in China and India: Multinationals, industry structure and development outcomes in the integrated circuit industry. Technological Forecasting and Social Change, 81, 1-10.

Fuller, D. B., Akinwande, A. I., \& Sodini, C. G. (2017). The globalization of R\&D's implications for technological capabilities in MNC home countries: Semiconductor design offshoring to China and India. Technological Forecasting and Social Change, 120, 14-23.

García Sánchez, A., Molero, J., \& Rama, R. (2016a). Are "the best" multinationals cooperating locally for innovation? The case of an intermediate country. Science \& Public Policy (SPP), 43(4), 532-545.

García Sánchez, A., Molero, J., \& Rama, R. (2016b). Local cooperation for innovation: food and beverage multinationals in a peripheral European country. International Journal of Multinational Corporation Strategy, 1(2), 107-132. 
García Sánchez, A., Molero, J., \& Rama, R. (2017). Patterns of local R\&D cooperation of foreign subsidiaries in an intermediate country: innovative and structural factors. Int. J. Technology Transfer and Commercialisation, 15(1), 38-64.

Geroski, P. A., \& Walters, C. F. (1995). Innovative Activity over the Business Cycle. The Economic Journal, 105(431), 916-928.

Granovetter, M. (2005). The impact of social structure on economic outcomes. Journal of Economic Perspectives, 19(1), 33-50.

Guimón, J. (2009). Government strategies to attract R\&D-intensive FDI. Journal of Technology Transfer, 34(4), 364-379.

Guimón, J., \& Salazar-Elena, J. C. (2015). Collaboration in innovation between foreign subsidiaries and local universities: evidence from Spain. Industry and Innovation, 22(6), 445-466.

Hansen, E., \& Nybakk, E. (2018). Response to the global financial crisis: a follow-up study. Journal of Innovation and Entrepreneurship, 7(1), 7.

Hoffmann, V. E., Belussi, F., Martínez-Fernández, M. T., \& Reyes, E. (2017). United we stand, divided we fall? Clustered firms' relationships after the 2008 crisis. Entrepreneurship \& Regional Development, 29(7-8), 735-758.

Holl, A., \& Rama, R. (2009). Networking and R\&D in domestic and FDI plants in Spanish Electronic Clusters. Int. J. Strategic Business Alliances, 1(2), 182-204.

Holl, A., \& Rama, R. (2014). Foreign subsidiaries and technology sourcing in Spain. Industry and Innovation, 21(1), 43-64.

Holl, A., \& Rama, R. (2016). Persistence of innovative activities in times of crisis: the case of the Basque Country. European Planning Studies, 24(10), 1863-1883.

Huang, S., \& Holden, D. (2016). The R\&D Boundaries of the Firm: A Problem-Solving Perspective. International Journal of the Economics of Business, 23(3), 287-317.

Jaklič, A., Damijan, J. P., Rojec, M., \& Kunčič, A. (2014). Relevance of innovation cooperation for firms' innovation activity: the case of Slovenia. Economic Research-Ekonomska Istraživanja, 27(1), 645-661.

Jugend, D., Jabbour, C. J. C., Alves Scaliza, J. A., Rocha, R. S., Junior, J. A. G., Latan, H., et al. (2018). Relationships among open innovation, innovative performance, government support and firm size: Comparing Brazilian firms embracing different levels of radicalism in innovation. Technovation, 74-75, 54-65.

Lincoln, J. R., Guillot, D., \& Sargent, M. (2017). Business groups, networks, and embeddedness: innovation and implementation alliances in Japanese electronics, 1985-1998. Industrial and Corporate Change, 26(3), 357-378.

López-Bayon, S., \& Gonzalez-Diaz, M. (2010). Indefinite contract duration: Evidence from electronics subcontracting. International Review of Law and Economics, 30(2), 145159.

Love, J. H., \& Roper, S. (2004). The organisation of innovation: collaboration, cooperation and multifunctional groups in UK and German manufacturing. Cambridge Journal of Economics, 28, 379-395.

Malerba, F. (2005). Sectoral systems: how and why innovation differs across sectors. In J. Fagerberg, D. C. Mowery \& R. R. Nelson (Eds.), The Oxford Handbook of Innovation (pp. 380-406). Oxford: Oxford University Press.

Manolopoulos, D. (2018). Entrepreneurship and Multinational Subsidiaries' Performance in an Era of Financial Crisis and Economic Uncertainty. Journal of East-West Business, 24(3), 170-187.

Manolopoulos, D., Papanastassiou, M., \& Pearce, R. (2005). Technology sourcing in multinational enterprises and the roles of subsidiaries: An empirical investigation. International Business Review, 14, 249-267. 
Mas, M., de Guevara, J. F., Robledo, J. C., Cardona, M., Lopez-Cobo, M., Righi, R., et al. (2018). The 2018 PREDICT Key Facts Report. An analysis of ICT R\&D in the EU and beyond: Joint Research Centre, EU (Seville site).

Miotti, L., \& Sachwald, F. (2003). Co-operative R\&D: why and with whom? An integrated framework of analysis. Research Policy, 32(8), 1481-1499.

Molero, J., \& Garcia, A. (2008). The innovative activity of foreign subsidiaries in the Spanish Innovation System: An evaluation of their impact from a sectoral taxonomy approach. Technovation, 28(11), 739-757.

Molero, J., \& Heijs, J. (2002). Differences of innovative behaviour between national and foreign firms: measuring the impact of foreign firms on national innovation systems. Int.J.Entrepreneurship and Innovation Management, 2(2/3),

Muñoz López, L., Antón Martínez, P. \& San Agustín García, A. (2017), Informe anual del sector TIC y de los contenidos en España 2017, Madrid: Gobierno de España.

OECD. (2008). The internationalization of business R\&D. Paris: OECD.

Paija, L. (2001). The ICT cluster: the engine of knowledge-driven growth in Finland. In OECD (Ed.), Innovative clusters. Drivers of National Innovation Systems (pp. 19-46). Paris: OECD.

Paunov, C. (2012). The global crisis and firms' investments in innovation. Research Policy, 41, 24-35.

Perri, A., \& Andersson, U. (2014). Knowledge outflows from foreign subsidiaries and the tension between knowledge creation and knowledge protection: Evidence from the semiconductor industry. International Business Review, 23(1), 63-75.

Phelps, N. A. (1993). Branch plant and the evolving spatial division of labour: a study of material linkage change in the Northern Region of England. Regional Studies, 27(2), 87101.

Rama, R. (2009). Foreign investment innovation. A review of selected policies The Journal of Technology Transfer, 33(4), 353-363.

Rama, R., \& Ferguson, D. (2007). Emerging districts facing structural reform: the Madrid electronics district and the reshaping of the Spanish telecom monopoly. Environment and Plannig A, 39, 2207-2231.

Santangelo, G. D. (2009). MNCs and linkages creation: Evidence from a peripheral area. Journal of World Business, 44(2), 192-205.

Srholec, M. (2009). Does foreign ownership facilitate cooperation on innovation? Firm-level evidence from the enlarged European Union. The European Journal of Development Research, 21(1), 47-62.

Srholec, M. (2014). Cooperation and Innovative Performance of Firms: Panel Data Evidence from the Czech Republic, Norway and the UK. Journal of the Knowledge Economy, 5(1), 133-155.

Suárez-Villa, L., \& Han, P.-H. (1990). The Rise of Korea's Electronics Industry: Technological Change, Growth, and Territorial Distribution. Economic Geography, 66(3), 273-292.

Teece, D. J. (2018). Tesla and the Reshaping of the Auto Industry. Management and Organization Review, 14(3), 501-512.

Un, C. A., \& Rodríguez, A. (2018). Local and global knowledge complementarity: R\&D collaborations and innovation of foreign and domestic firms. Journal of International Management, 24(2), 137-152.

Valdaliso, J., Elola, A., Aranguren, M. J., \& Lopez, S. (2011). Social capital, internationalization and absorptive capacity: The electronics and ICT cluster of the Basque Country.

Entrepreneurship \& Regional Development, 23(9-10), 707-733.

Veugelers, R., \& Cassiman, B. (2004). Foreign subsidiaries as a channel of international technology diffusion: Some direct firm level evidence from Belgium. European Economic Review, 48(2), 455-476. 
Williams, C., \& Ecker, B. (2011). R\&D subsidiary embedment: a resource dependence perspective. Critical perspectives on international business, 7(4), 297-325.

Williamson, O. E. (1985). The economic institutions of capitalism. New York and London: The Free Press.

Zaheer, S. (1995). Overcoming the Liability of Foreignness. Academy of Management 38(2), 341-363.

Zhang, S., Zhao, S., Bournakis, I., Pearce, R., \& Papanastassiou, M. (2018). Subsidiary roles as determinants of subsidiary technology sourcing: empirical evidence from China. Economia Politica, 1-26.

Zouaghi, F., \& Sánchez, M. (2016). Has the global financial crisis had different effects on innovation performance in the agri-food sector by comparison to the rest of the economy? Trends in Food Science \& Technology, 50, 230-242.

Zouaghi, F., Sánchez, M., \& García Martínez, M. (2018). Did the global financial crisis impact firms' innovation performance? The role of internal and external knowledge capabilities in high and low tech industries. Technological Forecasting and Social Change, 132, 92-104.

Wintjes, R. (2016), Systems and Modes of ICT Innovation, JRC Science for Policy Report, European Commission.

Witt, M. A. (2019). De-globalization: Theories, predictions, and opportunities for international business research. Journal of International Business Studies, 1-25. 
Table 1. Descriptive statistics

\begin{tabular}{|l|c|c|c|}
\hline Averages (std. dev) & $\begin{array}{c}\text { Unaffiliated } \\
\text { domestic firms }\end{array}$ & $\begin{array}{c}\text { Domestic } \\
\text { Groups }\end{array}$ & $\begin{array}{c}\text { Foreign } \\
\text { subsidiaries }\end{array}$ \\
\hline Turnover (1) & $\begin{array}{c}4,769.5 \\
(23,983.7)\end{array}$ & $\begin{array}{c}109,369.6 \\
(549,547.3)\end{array}$ & $\begin{array}{c}196,381.5 \\
(744,890.4)\end{array}$ \\
\hline Innovation expenditure (2) & $\begin{array}{c}416,413 \\
(3,743,335)\end{array}$ & $\begin{array}{c}5,013,271 \\
(29,773,893)\end{array}$ & $\begin{array}{c}8,567,730 \\
(40,241,381)\end{array}$ \\
\hline $\begin{array}{l}\text { Number of R\&D employees/1,000 } \\
\text { employees }\end{array}$ & 383 & 296 & 216 \\
& $(290)$ & $(286)$ & $(278)$ \\
\hline
\end{tabular}

Source: Author's own based on PITEC

Notes: (1) In thousands of $€$. (2) In $€$ 
Table 2. Predictors of local cooperation for innovation by types of firms

locCoopInn

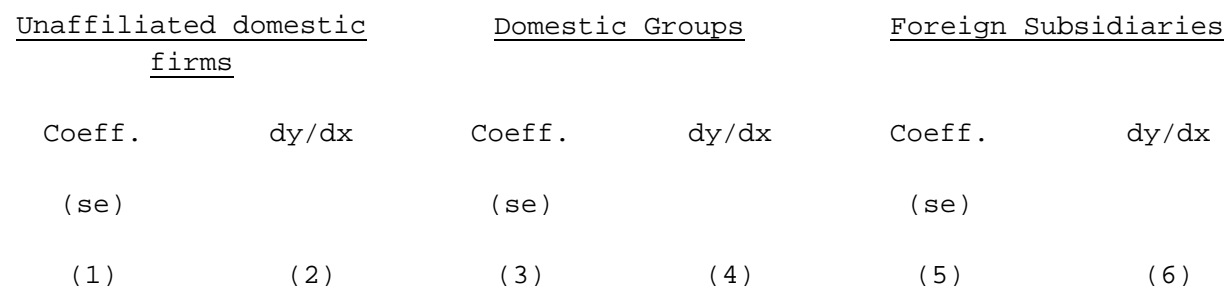

\begin{tabular}{|c|c|c|c|c|c|c|}
\hline previousLocCoop & $\begin{array}{l}1.74510^{* * *} \\
(0.198)\end{array}$ & $\odot .11128$ & $\begin{array}{l}2.21393^{* * *} \\
(0.222)\end{array}$ & $\odot .22680$ & $\begin{array}{l}1.86618^{* * *} \\
(0.353)\end{array}$ & $\odot .20680$ \\
\hline crisis & $\begin{array}{r}-0.10894 \\
(0.121)\end{array}$ & -0.00695 & $\begin{array}{r}-0.12644 \\
(0.148)\end{array}$ & -0.01295 & $\begin{array}{l}0.77382^{\star} \\
(0.303)\end{array}$ & $\odot .08575$ \\
\hline i_intRDExp & $\begin{array}{l}0.03084 \\
(0.149)\end{array}$ & $\odot .00197$ & $\begin{array}{c}-0.34345+ \\
(0.183)\end{array}$ & $-\odot .03518$ & $\begin{array}{c}-0.99580 * * \\
(0.356)\end{array}$ & -0.11035 \\
\hline i_extRDExp & $\begin{array}{l}0.99733^{* * *} \\
(0.191)\end{array}$ & 0.06359 & $\begin{array}{l}\odot .28078 \\
(0.234)\end{array}$ & 0.02876 & $\begin{array}{r}-0.23731 \\
(0.532)\end{array}$ & -0.02630 \\
\hline i_RDpers & $\begin{array}{r}-0.10779 \\
(0.236)\end{array}$ & $-\odot .00687$ & $\begin{array}{l}0.62457^{* *} \\
(0.196)\end{array}$ & $\odot .06398$ & $\begin{array}{l}1.51424^{* * *} \\
(0.419)\end{array}$ & $\odot .16780$ \\
\hline lsize & $\begin{array}{l}\odot .24839 * * * \\
(0.062)\end{array}$ & 0.01584 & $\begin{array}{l}0.29098 * * * \\
(0.061)\end{array}$ & 0.02981 & $\begin{array}{l}0.13110 \\
(0.116)\end{array}$ & $\odot .01453$ \\
\hline i_newmar & $\begin{array}{l}0.39853^{*} \\
(0.161)\end{array}$ & $\odot .02541$ & $\begin{array}{l}0.58851 * * * \\
(0.178)\end{array}$ & $\odot .06029$ & $-0.72622+$ & $-\odot .08048$ \\
\hline
\end{tabular}

$(0.388)$

\begin{tabular}{|c|c|c|c|c|c|c|}
\hline i_newent & $\begin{array}{l}0.22239 \\
(0.158)\end{array}$ & ๑. 01418 & $\begin{array}{l}\odot .85647^{* * *} \\
(0.179)\end{array}$ & 0.08774 & $\begin{array}{l}0.95358^{* *} \\
(\odot .369)\end{array}$ & $\odot .10567$ \\
\hline i_interinfo & $\begin{array}{l}0.34822^{*} \\
(0.138)\end{array}$ & 0.02220 & $\begin{array}{l}0.14783 \\
(0.163)\end{array}$ & $\odot .01514$ & $\begin{array}{l}1.03424^{* *} \\
(0.322)\end{array}$ & 0.11461 \\
\hline i_knowobst & $\begin{array}{l}0.21971 \\
(0.138)\end{array}$ & $\odot .01401$ & $\begin{array}{l}0.29725+ \\
(0.167)\end{array}$ & $\odot .03045$ & $\begin{array}{l}0.54240+ \\
(0.304)\end{array}$ & 0.06011 \\
\hline i_competobst & $\begin{array}{l}0.10179 \\
(0.141)\end{array}$ & $\odot .00649$ & $\begin{array}{l}0.36304^{*} \\
(0.163)\end{array}$ & 0.03719 & $\begin{array}{l}0.35765 \\
(0.331)\end{array}$ & ๑. 03963 \\
\hline i_marketobst & $\begin{array}{c}-0.31115^{*} \\
(0.134)\end{array}$ & -0.01984 & $\begin{array}{r}-0.23377 \\
(0.161)\end{array}$ & -0.02395 & $\begin{array}{l}0.06304 \\
(0.309)\end{array}$ & $\odot .00699$ \\
\hline Constant & $-7.65246 * * *$ & & $-7.59644 * * *$ & & $-5.85385^{* *}$ & \\
\hline
\end{tabular}


lnsig2u

Constant
$1.31560^{* * *}$
$\odot .91281$ ** *
1. $21751^{* * *}$
$(0.151)$
$(0.208)$
$(0.361)$

Prob > chi2

0.000

0.000

0.000

N. of cases

6068

2832

763

sigma_u

1.93054

1.57839

1.83814

rho

0.53115

0.43094

$\odot .50666$

Source: Authors' own based on PITEC provided by the Spanish National Institute of Statistics ( INE)

$+p<0.10, * p<0.05, * * p<0.01, * * * p<0.001$ 
Appendix 1. Description of variables

\begin{tabular}{|c|c|}
\hline Name of variable & Description of variable \\
\hline LocCooplnn & $\begin{array}{l}\text { Local cooperation for innovation (dependent variable) takes value } 1 \text { if the } \\
\text { firm has cooperated for innovation with local external partners for the } \\
\text { two previous years }\end{array}$ \\
\hline Fsub & Foreign subsidiary takes value 1 if the firm belongs to a foreign MNE \\
\hline DomG & $\begin{array}{l}\text { Domestic business group takes value } 1 \text { if the firm belongs to a business } \\
\text { group with headquarters in Spain }\end{array}$ \\
\hline i_ownfund & $\begin{array}{l}\text { Own funds takes value } 1 \text { if the company is more able than average to } \\
\text { fund its innovation projects with its own financial resources }\end{array}$ \\
\hline i_RDpers & $\begin{array}{l}\text { R\&D personnel takes value } 1 \text { if the firm hires more R\&D employees than } \\
\text { average }\end{array}$ \\
\hline i_newent & $\begin{array}{l}\text { New to the enterprise takes value } 1 \text { if the firm's share of improved } \\
\text { products in turnover is above average }\end{array}$ \\
\hline i_newmar & $\begin{array}{l}\text { New to the market takes value } 1 \text { if the firm's share of radically new } \\
\text { products in turnover is above average }\end{array}$ \\
\hline i_interinfo & $\begin{array}{l}\text { Internal sources of information takes value } 1 \text { if the firm values its internal } \\
\text { sources for innovation above average }\end{array}$ \\
\hline i_intRDexp & $\begin{array}{l}\text { Internal R\&D expenditures takes value } 1 \text { if the firm invests more than } \\
\text { average in internal R\&D }\end{array}$ \\
\hline i_extRDexp & $\begin{array}{l}\text { External R\&D expenditure takes value } 1 \text { if the firm invests more than } \\
\text { average in external R\&D }\end{array}$ \\
\hline i_otherlnnexp & $\begin{array}{l}\text { Other innovation expenditures takes value } 1 \text { if the firm invests more than } \\
\text { average in innovation expenditures other than } R \& D\end{array}$ \\
\hline i_knowlobst & $\begin{array}{l}\text { Knowledge obstacles takes value } 1 \text { if the firm encounters greater-than- } \\
\text { average knowledge obstacles to innovation }\end{array}$ \\
\hline i_econobs & $\begin{array}{l}\text { Economic obstacles takes value } 1 \text { if the firm encounters greater-than- } \\
\text { average economic obstacles to innovation }\end{array}$ \\
\hline i_marketobstacles & $\begin{array}{l}\text { Market obstacles takes value } 1 \text { if the firm encounters greater-than- } \\
\text { average market obstacles to innovation }\end{array}$ \\
\hline i_competobst & $\begin{array}{l}\text { Competition obstacles takes value } 1 \text { if the firm encounters greater-than- } \\
\text { average competition obstacles to innovation }\end{array}$ \\
\hline crisis & 2008-2014 signals the in-crisis period \\
\hline i_size & $\begin{array}{l}\text { Size takes value } 1 \text { if the firm is larger than average in terms of number of } \\
\text { employees }\end{array}$ \\
\hline L_size & Logarithm of the number of employees \\
\hline mdoue & $\begin{array}{l}\text { European Union market takes value } 1 \text { if the firm exports goods or services } \\
\text { to the EU }\end{array}$ \\
\hline Previous LocCoop & $\begin{array}{l}\text { Previous local cooperation takes value } 1 \text { if the firm reported local } \\
\text { cooperation for innovation for the two previous years }\end{array}$ \\
\hline
\end{tabular}




\section{Appendix 2. Correlation matrix.}

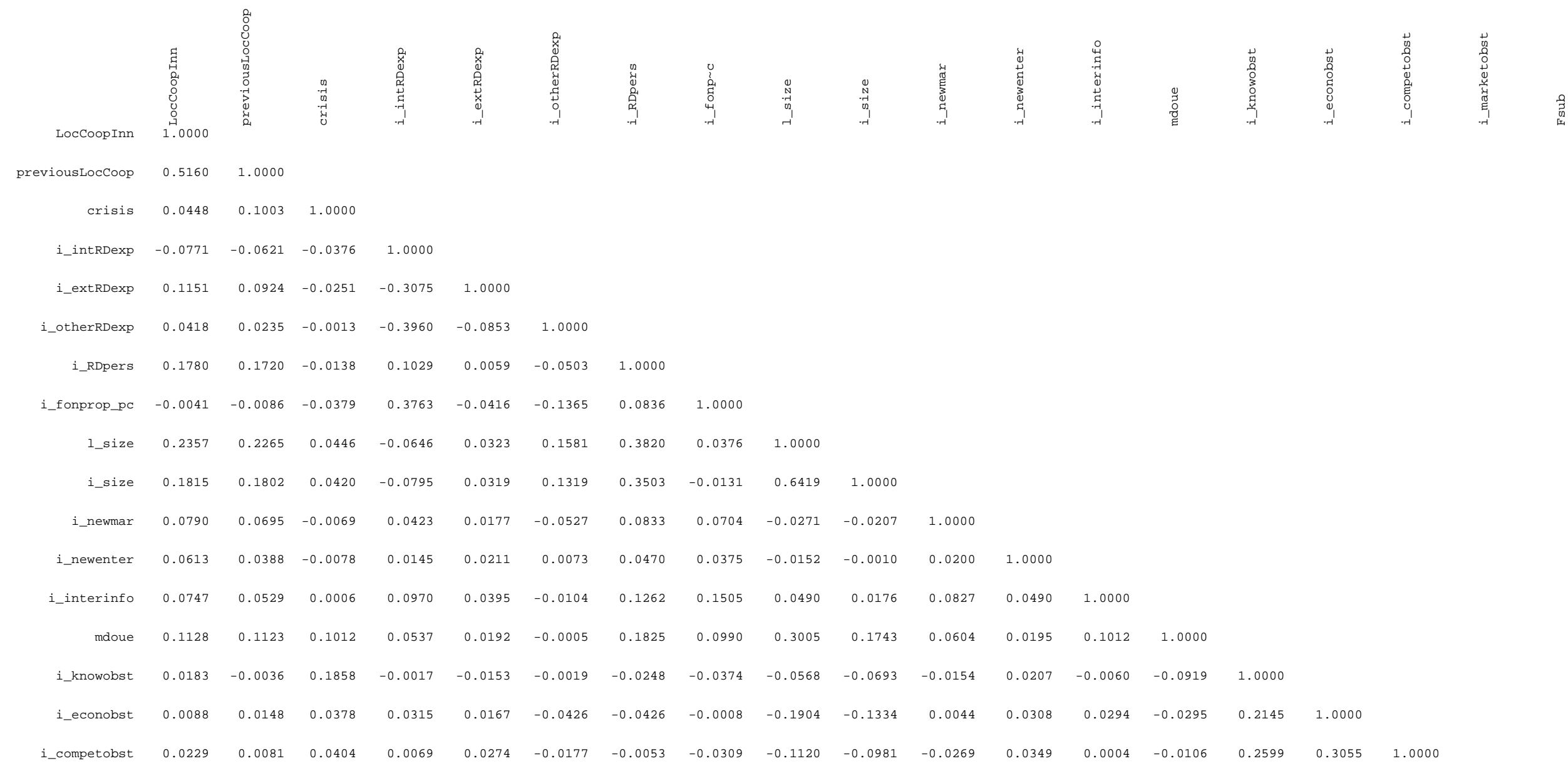




\begin{tabular}{|c|c|c|c|c|c|c|c|c|c|c|c|c|c|c|c|c|c|c|c|}
\hline i_merketobst & -0.0571 & -0.0520 & 0.0257 & -0.0713 & -0.0301 & 0.0396 & -0.0979 & -0.0766 & -0.0275 & -0.0064 & -0.0548 & -0.0092 & -0.1142 & -0.0679 & 0.1672 & 0.0477 & 0.1078 & & \\
\hline & & & & & & & & & & & & & & & & & & 1.0000 & \\
\hline Fsub & 0.1048 & 0.0921 & 0.0195 & -0.0345 & -0.0045 & 0.0492 & 0.1225 & -0.0100 & 0.3075 & 0.3171 & -0.0060 & -0.0200 & 0.0306 & 0.1780 & -0.0643 & -0.1529 & -0.0956 & -0.0179 & 1.0000 \\
\hline
\end{tabular}


${ }^{1}$ https://www.acea.be/statistics/tag/category/eu-production. December 2018.

2 http://www.investinspain.org/invest/es/sectores/automocion/descripcion/index.html Government of Spain, December 2018 (data for 2017).

${ }^{3}$ https://www.afm.es/es/quienes-somos/sector-maquina-herramienta, December 2018

${ }^{4}$ CIS-type surveys, such as PITEC, do not provide data to measure actual technological transfers from FSubs to host countries (Veugelers \& Cassiman, 2004).

${ }^{5}$ OECD, "FDI qualities Toolkit: Investment for Sustainable Growth: Progress Report II", Paris, October 2018. 